University of Nebraska - Lincoln

DigitalCommons@University of Nebraska - Lincoln

2006

\title{
Landscape context mediates influence of local food abundance on wetland use by wintering shorebirds in an agricultural valley
}

Oriane W. Taft

USGS Forest and Rangeland Ecosystem Science Center, oriane_taft@usgs.gov

Susan M. Haig

USGS Forest and Rangeland Ecosystem Science Center, Susan_Haig@usgs.gov

Follow this and additional works at: https://digitalcommons.unl.edu/usgsstaffpub

Taft, Oriane W. and Haig, Susan M., "Landscape context mediates influence of local food abundance on wetland use by wintering shorebirds in an agricultural valley" (2006). USGS Staff -- Published Research. 575.

https://digitalcommons.unl.edu/usgsstaffpub/575

This Article is brought to you for free and open access by the US Geological Survey at DigitalCommons@University of Nebraska - Lincoln. It has been accepted for inclusion in USGS Staff -- Published Research by an authorized administrator of DigitalCommons@University of Nebraska - Lincoln. 


\title{
Landscape context mediates influence of local food abundance on wetland use by wintering shorebirds in an agricultural valley
}

\author{
Oriane W. Taft ${ }^{a, b, *}$, Susan M. Haig ${ }^{a}$ \\ ${ }^{a}$ USGS Forest and Rangeland Ecosystem Science Center, 3200 SW Jefferson Way, Corvallis, OR 97331, USA \\ ${ }^{\mathrm{b}}$ Department of Fisheries and Wildlife, Oregon State University, Corvallis, OR 97331, USA
}

\section{A R T I C L E I N F O}

\section{Article history:}

Received 9 August 2004

Received in revised form 8 June 2005

Accepted 28 September 2005

Available online 11 November 2005

\section{Keywords:}

Benthic invertebrates

Dunlin (Calidris alpina)

Killdeer (Charadrius vociferus)

Wetland landscape planning

Wetland conservation

Willamette Valley of Oregon

\begin{abstract}
A B S T R A C T
While it is widely understood that local abundance of benthic invertebrates can greatly influence the distribution and abundance of wetland birds, no studies have examined if wetland landscape context can mediate this relationship. We studied the influence of wetland food abundance and landscape context on use of agricultural wetlands by wintering dunlin (Calidris alpina) and killdeer (Charadrius vociferus) in the Willamette Valley of Oregon, USA, over two winters (1999-2000, 2000-2001) of differing rainfall and subsequent habitat distribution. We monitored bird use (frequency of occurrence and abundance) at a sample of wetlands differing in local food abundance (density and biomass) and landscape context [adjacent shorebird habitat (defined as ha of wet habitat with less than $50 \%$ vegetative cover and within a $2-\mathrm{km}$ radius) and nearest neighbor distance]. We evaluated predictive models for bird use using linear regression and the Cp criterion to select the most parsimonious model. During the dry winter (2000-2001), dunlin exhibited greater use of sites with higher invertebrate density and biomass but also with more adjacent shorebird habitat and closest to a wetland neighbor. However, neither landscape context nor food abundance were important predictors of dunlin use during the wet winter (1999-2000). Use of sites by killdeer was unrelated to either local food abundance or landscape context measures during both winters. Our findings contribute to a growing recognition of the importance of landscape structure to wetland birds and highlight a number of implications for the spatial planning and enhancement of wetlands using a landscape approach.
\end{abstract}

Published by Elsevier Ltd.

\section{Introduction}

Only in the last decade have researchers considered landscape-scale influences on use of individual wetlands by wetland birds (e.g., Farmer and Parent, 1997; Elphick, 1998; Naugle et al., 1999; Calmé and Desrochers, 2000; Fairbairn and Dinsmore, 2001; Riffell et al., 2003; Shriver et al., 2004; Taft and Haig, in press). In contrast, wetland ecology has a long history of researching the local wetland habitat characteris- tics that influence the distribution and abundance of wetland birds (e.g., Kadlec, 1962; Weller, 1978, 1987; Murkin et al., 1997). One tenet that has emerged from this traditional sitebased approach is that invertebrate prey resources play a central role in determining waterbird distributions (e.g., wading birds, waterfowl, shorebirds) within and among wetlands during the nonbreeding season (e.g., Evans and Dugan, 1984; Goss-Custard, 1984; Murkin and Kadlec, 1986; Helmers, 1991; Krapu and Reinecke, 1992; Colwell and Landrum, 1993; Kalejta

\footnotetext{
* Corresponding author: Tel.: +1 541750 7390; fax: +1 5417588806 .

E-mail address: oriane_taft@usgs.gov (O.W. Taft). 
and Hockey, 1994; Mercier and McNeil, 1994; Safran et al., 1997; Weber and Haig, 1996, 1997; Farmer and Wiens, 1999; Ashley et al., 2000). However, particularly during nonbreeding periods, many waterbirds are highly mobile (e.g., Haig et al., 1998; Roshier et al., 2002) and thus likely to first interact with the structure of wetland landscapes, or the distribution of wetland resources at large spatial scales. Whether the landscape context of wetland sites (i.e., spatial pattern of habitat surrounding sites) can influence the importance of local food resources to waterbirds is a novel question for wetland ecology, and one whose answers may have significant implications for conservation planning of entire wetland landscapes (Wu and Hobbs, 2002).

Landscape structure likely influences waterbird foraging dynamics during the winter period. For this season in particular, invertebrate resources at temperate latitudes can be scarce and patchily distributed over large distances (e.g., Evans, 1976; Myers, 1983) and thus waterbirds likely supplement their energy intake by using multiple wetlands within a landscape (sensu Dunning et al., 1992). Moreover, the energetic costs of flight, thermoregulation and survival can be high (e.g., Kersten and Piersma, 1987; Castro and Myers, 1989). Consequently, it should be energetically favorable for wintering waterbirds to concentrate in areas with proportionately high wetland densities (Evans, 1976; Pyke, 1983; Farmer and Parent, 1997). As a result, discovery (and subsequent revisiting) of wetland sites with high food abundance may be influenced by their particular location in the landscape: highly productive sites that are isolated may be used less than those located in concentrated wetland regions, and less productive sites surrounded by much wetland habitat may sustain greater use than if they were isolated.

We examined the influence of wetland food abundance and landscape context on winter use of wetlands by two shorebird species (dunlin Calidris alpina and killdeer Charadrius vociferus) in the agricultural wetland landscape of the Willamette Valley in western Oregon, USA ("Valley"). The Valley is winter residence to 40,000 or more shorebirds, of which dunlin and killdeer are the most abundant species (Sanzenbacher and Haig, 2002a,b; Taft and Haig, 2003). These two species represent two ends of the spectrum of Valley shorebird ecologies as dunlin favor moist or flooded substrates while killdeer are considered habitat generalists (Warnock and Gill, 1996; Jackson and Jackson, 2000). Valley wetlands used by shorebirds are primarily on privately owned agricultural wetlands ('palustrine emergent-farmed wetlands' of Cowardin et al., 1979), flooded farmlands that annually develop with the accumulation of winter rains on native hydric soils (Taft and Haig, 2003; Taft et al., 2004). On these agricultural wetlands, shorebirds find accessible foraging habitat where farming practices provide exposed soil. Different management histories among sites have presumably generated wetlands varying in invertebrate abundance (Taft and Haig, 2005). However, in accordance with the variable distribution of hydric soils, agricultural wetlands also vary considerably in spatial configuration across the Valley landscape (Taft et al., 2004).

During two winters of differing rainfall and subsequent habitat distribution, our objectives were to: (1) determine if wetland use (frequency of occurrence and bird abundances) was related to measures of wetland invertebrate food abundance, and (2) assess the additional variation in bird use explained by considering wetland landscape context. We conclude by evaluating implications of our findings to wetland conservation in the Valley and other similar wetland landscapes.

\section{Study area}

The greater Willamette Valley encompasses $9100 \mathrm{~km}^{2}$ of lowland plains (Clark et al., 1991; Benner and Sedell, 1997) within Oregon's Willamette Basin, a 29,000 km² watershed between Oregon's Cascade and Coast Ranges (Fig. 1; Hulse et al., 2002; Benner and Sedell, 1997). The prominent hydrologic feature of the Valley is the Willamette River and its 13 major tributaries. The climate is cool Mediterranean, with an average annual rainfall of 100-125 cm, 75\% of it falling between October and March (Jackson and Kimerling, 1993); average temperatures range from $1^{\circ} \mathrm{C}$ in January to $30^{\circ} \mathrm{C}$ in July (data from Oregon Climate Service: http://www.ocs.oregonstate.edu/index.html). We conducted our study from November to March of 1999-2000 and 2000-2001, two winters that differed dramatically in rainfall: $91 \mathrm{~cm}$ in 1999-2000 vs. $40 \mathrm{~cm}$ in 2000-2001 from October to March (Oregon Climate Service). Consequently, we refer to winter 1999-2000 as the 'wet winter' and to winter 2000-2001 as the 'dry winter.'

Common Valley lowland crops include grass seed (most prevalent), vegetables, grains, and peppermint (Hulse et al., 2002). Grass seed crops are planted in autumn. Whereas annual ryegrass (Lolium multiflorum) fields are covered fully with vegetation by mid to late winter, newly-planted perennial ryegrass (L. perenne) fields have exposed soil between plants throughout the winter. Vegetable crops are left fallow through the winter and replanted in spring. Many of these crops are planted on what were historical wetlands and thus where soils are poorly-drained (Taft and Haig, 2003).

We selected 17 (in the wet winter) and 19 (in the dry winter) study wetlands in the northeast portion of the southern Valley, a $480 \mathrm{~km}^{2}$ area of lowland plain encompassing the Calapooia River, a third to fourth order tributary of the Willamette River (Fig. 1; Office of Information Resources Management, 1994). This area is characterized by a high incidence of poorly-drained hydric soils interspersed among well-drained areas (Daggett et al., 1998) providing an array of configurations of wetland habitat surrounding sites (varying landscape contexts). Because ponding on agricultural fields tends to occur as widely scattered, irregularly shaped, dynamic areas of shallow (1-cm deep) non-flowing sheetwater, we considered entire agricultural fields as sites. We non-randomly chose sites based on four criteria: (1) access granted by landowners, (2) regular spatial interspersion, (3) presence of ponding or saturated soil, and (4) shorebird access to the wet substrate (vegetation cover $\leqslant 50 \%$ throughout the winter). We also chose study sites to comprise a diversity of agricultural cover types representing proportions of the greater Valley in each [wet winter: $65 \%$ in grass seed, $18 \%$ fallow, $12 \%$ pasture, and $6 \%$ other (wild rice pond); dry winter: $62 \%$ in grass seed, $16 \%$ fallow, $12 \%$ pasture, and $5 \%$ other (wild rice pond); J. Steiner, USDA Agricultural Research Service, personal communication]. 


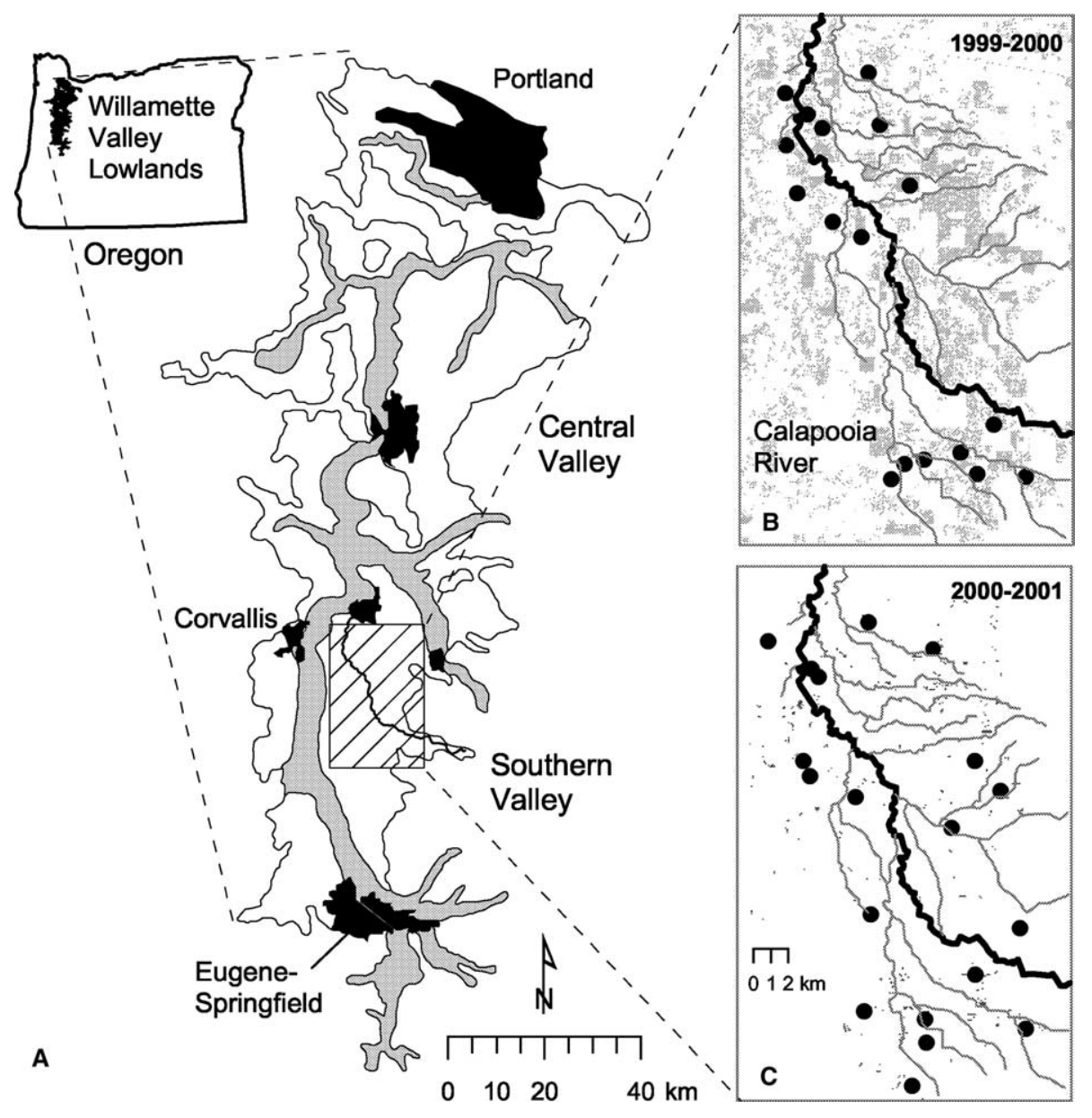

Fig. 1 - Location of agricultural wetlands studied during the winters of 1999-2000 (wet) and 2000-2001 (dry) within the southern Willamette Valley of Oregon, USA. (A) Area in gray depicts the Willamette River floodplain, area in white depicts Valley alluvial terraces, and areas in black are urban. Hatched box portrays enlarged study area encompassing alluvial terraces surrounding the Calapooia River. (B) Location of 17 agricultural wetlands studied in the wet winter of 1999-2000. Shorebird habitat is shown in gray. (C) Location of 19 agricultural wetlands studied in the dry winter of 2000-2001. Shorebird habitat is shown in black. Major streams of the Calapooia shown at 1:100,000 scale (Office of Information Resources Management, 1994).

\section{Methods}

\subsection{Land-cover data}

Shorebirds prefer moist to flooded foraging substrates that are sparsely vegetated (Rundle and Fredrickson, 1981; Fredrickson and Reid, 1986; Colwell and Oring, 1988; Rottenborn, 1996). Moreover, prior to data collection, we observed an association between shorebird use and wet exposed ( $\leqslant 50 \%$ vegetation cover) portions of agricultural land (hereafter shorebird habitat), particularly for dunlin and their ecological allies (family Scolopacidae). Thus, for both winters, we mapped the distribution of shorebird habitat in our focal study area using a combination of remotely sensed imagery and data acquired in the field (Taft et al., 2004; Taft and Haig, in press). For the wet winter of 1999-2000, we used radar (RADARSAT International, http://www.rsi.ca) imagery taken 28 January to produce a layer in a geographic information system (GIS; Erdas Imagine 8.6, Erdas, Inc., Atlanta, GA) depicting the midwinter distribution of shorebird habitat during peak wetness. Shallow water within impounded semi-natural wetlands was mapped as shorebird habitat. Taft et al. (2004) provide details on creation of land-cover maps from radar data.

Because analogous satellite imagery was not available in the dry winter of 2000-2001, we produced a land-cover layer of shorebird habitat for mid-winter by ground mapping visible habitat in February 2001 during and after the period of peak winter wetness. Using visible landmarks that were also depicted on topographic maps (USGS $7.5 \mathrm{~min}$ ), we plotted shorebird habitat on field maps and digitized these into a GIS layer (in Erdas Imagine 8.6). Because we recorded the among-survey maximum $\%$ of wet habitat on study wetlands during shorebird surveys (see below), we were able to verify ground-mapped estimates of shorebird habitat on study sites. Even distribution and density of roads across the Valley (Hulse et al., 2002) promoted consistent visibility of shorebird habitat throughout the study region. 


\subsection{Shorebird surveys}

Although Valley wintering shorebirds forage nocturnally (Sanzenbacher and Haig, 2002a,b), we only surveyed study sites during daylight hours (0730-1800). We surveyed sites at weekly intervals and on the days we sampled for invertebrates, yielding 19 (in the wet winter) and 18 (in the dry winter) weekly surveys from November to March. At each survey, we identified and counted all shorebirds present at each site with $8 \times$ binoculars and $25 \times$ spotting scopes. We alternated weekly the survey time of day (morning, afternoon) for each site to reduce time-of-day biases. We used land-cover maps and landmarks that were both mapped and visible in the field (e.g., topography, creek-road crossings, railroads) to locate and digitize in a GIS layer (in Erdas Imagine 8.6) the center points and approximate perimeters of all sites. From these GIS data, we calculated the area (ha) of each site. At the time of each survey, we visually estimated $\%$ of site with ponded water or saturated soil.

\subsection{Invertebrate sampling}

We sampled benthic and surface-dwelling invertebrates at each site once during mid to late winter: between 31 January and 15 February in 1999-2000, and between 5 January and 5 March in 2000-2001. We collected 15 core samples per site during each sampling event in the wet winter, and 30 samples per site in the dry winter. Each sample was a 5 -cm diameter cylindrical core pushed $5 \mathrm{~cm}\left(98 \mathrm{~cm}^{3}\right)$ into the benthos (Sherfy et al., 2000) and retaining any invertebrates present on the soil surface. We sampled invertebrates within an oblong area roughly 150 by $20 \mathrm{~m}$ encompassing concentrated wet areas within sites. Within sample areas, we systematically collected one sample every $10 \pm 2 \mathrm{~m}$ along a linear zig-zagging transect. Half of all core samples at each site were collected in flooded habitat (less than $5 \mathrm{~cm}$ deep) and half in nonflooded but moist/saturated habitat.

Samples were washed, sieved (500 $\mu \mathrm{m}$ mesh), and preserved in $70 \%$ ethanol solution within two days of collecting (kept refrigerated until sieved and fixed). Using a stereomicroscope at 30x, we sorted through sieved debris and identified, counted, and collected all invertebrates of taxonomic groups that have been documented in shorebird diets (Skagen and Oman, 1996) and that were probable prey items for dunlin and killdeer (Warnock and Gill, 1996; Jackson and Jackson, 2000). We used Pennak (1989) and Merrit and Cummins (1984) to identify these to the family level for Oligochaeta (Enchitraeidae, Tubificidae, Lumbricidae) and most Insecta larvae (Chironomidae, Empididae, Tipulidae), but identified only to subclass for ostracods (Ostracoda) and order for haplotaxid oligochaetes (Haplotaxida), springtails (Collembola), and caddisfly larvae (Trichoptera).

The body size of individuals of each identified group appeared to vary little among sites and between years. Consequently, we estimated dry biomass of samples by drying (at $50{ }^{\circ} \mathrm{C}$ for $24 \mathrm{~h}$ ) and weighing (to nearest $0.0001 \mathrm{~g}$ ) a variable collection (i.e., some small, some large) of individuals in each group from all sites studied in 2000-2001 (360 small oligochaetes, 50 lumbricids, 38 chironomids, 10 empids, 23 tipulids and 20 trichoptera). We then divided total biomass for each group by the number of collected individuals to generate average biomass multipliers used in conjunction with counts of individuals to calculate estimated total biomass of each sample.

\subsection{Data summary and analyses}

Because study wetlands provided foraging habitat for shorebirds, we included all birds present at sites at the time of survey (even if resting) to be potential foragers, and included all individuals in total counts for presence and abundance. We summarized site use data collected across all surveys $(n=19$ in wet winter, $n=18$ in dry winter) to generate two response variables for each species: (1) frequency of occurrence (proportion of surveys in which species was present), and (2) mean bird abundance among surveys.

We generated two measures indexing local food abundance within sites each winter: (1) mean invertebrate density (individuals $/ \mathrm{m}^{2}$ ), calculated as the mean number of invertebrates among collected core samples at a site, and (2) mean invertebrate biomass $\left(\mathrm{mg} / \mathrm{m}^{2}\right)$, calculated as the mean estimated invertebrate dry biomass among cores in a site. Owing to differences in diet and foraging modes between dunlin and killdeer, we calculated food abundance measures differently for each species. Although shorebirds have been known to take invertebrates (e.g., ostracods) as small as $1.0 \mathrm{~mm}$ long (Weber and Haig, 1997), we did not feel that we had adequately sampled nektonic and mobile small invertebrates such as ostracods and springtails, respectively, and thus excluded these from analyses for both species. However, we included all other identified invertebrates in food abundance estimates for dunlin analyses. For killdeer analyses, we additionally excluded small oligochaetes (Enchitraeidae, Tubificidae, Haplotaxida) which we regarded as too small and inaccessible to foraging killdeer.

We defined two predictors describing wetland landscape context: (1) adjacent shorebird habitat (ha) and (2) nearest neighbor distance $(\mathrm{m})$. We considered adjacent shorebird habitat as the amount of shorebird habitat in a $2 \mathrm{~km}$ radius surrounding sites each winter, calculated using our GIS layers for land cover in ArcView 3.2 (ESRI, Inc., Redlands, CA) to delineate area of habitat within circular buffers centered on each site's central coordinates. We chose $2 \mathrm{~km}$ as an operative radius that would capture variation among sites in amount of adjacent habitat while also minimizing spatial autocorrelation among sites in landscape context measures due to overlapping buffers. Moreover, we considered a $2 \mathrm{~km}$ radius as an appropriate average spatial scale at which dunlin and killdeer likely interact with the landscape (in a concurrent study of the winter home ranges of radio-tagged individuals, core use areas had roughly a $3 \mathrm{~km}$ radius for dunlin and a $1.5 \mathrm{~km}$ radius for killdeer; Sanzenbacher and Haig, 2002a,b; P. Sanzenbacher, U.S. Geological Survey, personal communication). Because distance to the closest adjacent habitat could differ for two sites with the same amount of surrounding habitat within $2 \mathrm{~km}$, we included nearest neighbor distance as an additional measure quantifying landscape context. We calculated the nearest neighbor distance as the Euclidean distance $(\mathrm{m})$ from the midpoint of sample sites to the nearest shorebird habitat edge. Finally, we calculated wet area (ha) by multiplying the mean \% 
(among surveys) of site flooded/saturated by the site's area (ha).

For each winter, we used linear regression to evaluate the influence of one of the two food abundance estimates (mean invertebrate density, mean invertebrate biomass) and both landscape context predictors (adjacent shorebird habitat and nearest neighbor distance) on each of the species use response variables (frequency of occurrence and mean bird abundance). Where necessary, we natural log (ln) transformed mean abundance responses to meet the assumptions of regression. We adjusted mean bird abundances for local habitat area by including wet area as a covariate in all models. For both winters, weak associations between wet area and adjacent shorebird habitat, and between adjacent shorebird habitat and nearest neighbor distance (correlation coefficients between 0.1 and 0.3; Cohen, 1988) allowed for simultaneous assessment of their influences on bird use. We considered all combinations of predictors biologically plausible, and used the $\mathrm{Cp}$ criterion to select the most parsimonious regression model (Ramsey and Schafer, 1997). We lowered type I error rate due to potential violations of independence (from the few sites whose $2 \mathrm{~km}$ buffers overlapped) by considering model terms significant only if $P$-values were $<0.01$. Partial $R^{2}$ values are provided for significant model terms only. All regression analyses were performed using proc REG (SAS Institute Inc., 1999).

\section{Results}

Study wetlands varied considerably both in estimated local food abundance and measures of landscape context (Table 1). Mean invertebrate densities and biomass varied among sites each year. However, landscape context measures differed more among sites in the dry winter than the wet winter, as illustrated by comparing coefficients of variation (dry vs. wet winter: adjacent shorebird habitat: 0.47 vs. 0.26 ; nearest neighbor distance: 0.62 vs. 0.43 ) and ratios of maximum to minimum values (adjacent shorebird habitat differed by a factor of 7 in the dry winter but only by a factor of 2 in the wet winter; nearest neighbor distances differed by a factor of 11 in the dry winter compared to a factor of 4 in the wet winter). While killdeer numbers were similar between winters, dunlin were far less abundant at sites in the dry winter of 20002001.

In both winters, local food abundance and both measures of landscape context had low explanatory power in explaining variation in frequency of occurrences of dunlin and killdeer (Tables 2 and 3). Wet area did not account for much variation in dunlin or killdeer abundances in either winter (Tables 2 and 3). However, during the dry winter only, mean dunlin abundances were greater at sites with more food (both measures), but also with more adjacent shorebird habitat (Table 2). Adjacent shorebird habitat accounted for the most variation in dunlin abundance among sites ( $R^{2}$ of 0.34 ), with food abundance explaining up to half of the remaining variation $\left(R^{2}\right.$ ranging from 0.23 to 0.26 ). In addition, nearest neighbor distance was an important predictor explaining variation in mean dunlin abundances in one of two analyses. In contrast, during the wet winter, local food abundance and landscape context of sites had low explanatory power in explaining variation in dunlin abundances at sites. Likewise, variation in killdeer abundances among sites had relatively little to do with local food abundance and the landscape context of sites in either winter (Table 3).

Table 1 - Mean ( \pm SD) site features (predictors) and dunlin and killdeer use (responses) among 17 (wet winter 1999-2000) and 19 (dry winter 2000-2001) sites monitored throughout the winter (November-March) in the Willamette Valley, Oregon, USA

\begin{tabular}{|c|c|c|c|c|}
\hline \multirow[t]{2}{*}{ Parameters } & \multicolumn{2}{|c|}{ Wet winter 1999-2000 } & \multicolumn{2}{|c|}{ Dry winter 2000-2001 } \\
\hline & Mean \pm SD & Range & Mean \pm SD & Range \\
\hline \multicolumn{5}{|l|}{ Site Predictors } \\
\hline Wet area (ha) & $4.3 \pm 3.3$ & $0.4-12.4$ & $3.5 \pm 2.8$ & $0.5-9.3$ \\
\hline Mean invertebrate density ${ }^{\mathrm{a}}$ for dunlin $\left(\# / \mathrm{m}^{2}\right)$ & $976 \pm 473$ & 173-1925 & $1113 \pm 881$ & $208-3,487$ \\
\hline Mean invertebrate density ${ }^{\mathrm{a}}$ for killdeer $\left(\# / \mathrm{m}^{2}\right)$ & $113 \pm 67$ & 14-309 & $139 \pm 148$ & 19-659 \\
\hline Mean invertebrate biomass ${ }^{b}$ for dunlin $\left(\mathrm{mg} / \mathrm{m}^{2}\right)$ & $356 \pm 139$ & $35-643$ & $423 \pm 306$ & $85-1405$ \\
\hline Mean invertebrate biomass ${ }^{b}$ for killdeer $\left(\mathrm{mg} / \mathrm{m}^{2}\right)$ & $184 \pm 130$ & $3-590$ & $228 \pm 228$ & $39-839$ \\
\hline Adjacent shorebird habitat ${ }^{\mathrm{c}}$ (ha) & $294 \pm 76$ & $214-486$ & $19 \pm 9$ & $5-35$ \\
\hline Nearest neighbor distance ${ }^{\mathrm{d}}(\mathrm{m})$ & $388 \pm 168$ & 200-815 & $593 \pm 369$ & $150-1602$ \\
\hline \multicolumn{5}{|l|}{ Bird use responses } \\
\hline Dunlin frequency of occurrence $(\%)$ & $18 \pm 13$ & $0-47$ & $15 \pm 13$ & $0-50$ \\
\hline Killdeer frequency of occurrence ${ }^{\mathrm{e}}(\%)$ & $41 \pm 26$ & $5-84$ & $46 \pm 19$ & 17-78 \\
\hline Mean dunlin abundance ${ }^{f}$ (\# birds) & $212 \pm 390$ & $0-1531$ & $31 \pm 26$ & $0-98$ \\
\hline Mean killdeer abundance ${ }^{f}$ (\# birds) & $39 \pm 50$ & $1-216$ & $38 \pm 23$ & $2-102$ \\
\hline \multicolumn{5}{|c|}{$\begin{array}{l}\text { a Mean number of invertebrates (all taxonomic groups combined) per } \mathrm{m}^{2} \text { among collected core samples }(n=15 \text { in } 1999-2000, n=30 \text { in } 2000- \\
2001) \text {. } \\
\text { b Mean estimated biomass ( } \mathrm{mg} / \mathrm{m}^{2} \text {; all taxonomic groups combined) among collected core samples }(n=15 \text { in } 1999-2000, n=30 \text { in } 2000-2001) \text {. } \\
\text { c Amount (ha) of class } 1 \text { habitat within } 2 \mathrm{~km} \text { of the central coordinates of the site. } \\
\text { d Euclidean distance }(\mathrm{m}) \text { from the midpoint of sample sites to the nearest shorebird habitat edge. } \\
\text { e Frequency of occurrence among all surveys conducted ( } n=19 \text { in } 1999-2000, n=18 \text { in 2000-2001). } \\
\text { f Mean bird abundance among all surveys conducted. }\end{array}$} \\
\hline
\end{tabular}


Table 2 - Results of linear regressions of dunlin use (frequency of use, mean bird abundance) on one of two food

abundance measures [mean invertebrate density (individuals $/ \mathrm{m}^{2}$ ) or biomass $\left(\mathrm{mg} / \mathrm{m}^{2}\right)$ ] and landscape context [adjacent

shorebird habitat (ha) and nearest neighbor distance $(\mathrm{m})]$ of wetland sites during two winters in the Willamette Valley, Oregon, USA

\begin{tabular}{|c|c|c|c|c|c|c|c|c|c|}
\hline Winter & Bird use response & $\begin{array}{l}\text { Parameters in model } \\
\text { with lowest } \mathrm{Cp}\end{array}$ & $\begin{array}{c}\text { Parameter } \\
\text { estimate }( \pm S E)\end{array}$ & $\begin{array}{c}\text { t- } \\
\text { value }\end{array}$ & $\begin{array}{c}P \text { - } \\
\text { value }\end{array}$ & $\begin{array}{c}\text { Partial } \\
\mathrm{R}^{2}\end{array}$ & $\begin{array}{c}F- \\
\text { value }\end{array}$ & $\begin{array}{c}\text { P- } \\
\text { value }\end{array}$ & $\begin{array}{l}\text { Model } \\
\text { adj. } R^{2}\end{array}$ \\
\hline \multirow{11}{*}{$\begin{array}{l}\text { Wet } \\
1999-2000 \\
\text { Dry } \\
\quad 2000-2001\end{array}$} & \multirow{2}{*}{$\begin{array}{l}\text { Frequency of occurrence }{ }^{a} \\
\text { Mean bird abundance }{ }^{b, c}\end{array}$} & Wet area & $1.12 \pm 0.99$ & 1.14 & 0.27 & - & 1.29 & 0.27 & 0.02 \\
\hline & & Wet area & $0.30 \pm 0.15$ & 2.11 & 0.05 & - & 4.43 & 0.05 & 0.18 \\
\hline & \multirow{9}{*}{$\begin{array}{l}\text { Frequency of occurrence } \\
\text { Mean bird abundance }\end{array}$} & Nearest neighbor distance $^{d}$ & $-0.01 \pm 0.008$ & -1.90 & 0.07 & - & 3.61 & 0.07 & 0.13 \\
\hline & & Wet area & $0.90 \pm 1.45$ & 0.62 & 0.55 & - & 8.27 & 0.0012 & 0.62 \\
\hline & & Mean invertebrate density & $0.02 \pm 0.005$ & 3.90 & 0.0016 & 0.23 & & & \\
\hline & & Adjacent shorebird habitat ${ }^{\mathrm{f}}$ & $1.64 \pm 0.47$ & 3.51 & 0.0035 & 0.34 & & & \\
\hline & & Nearest neighbor distance & $-0.03 \pm 0.01$ & -2.53 & 0.02 & 0.14 & & & \\
\hline & & Wet area & $0.92 \pm 1.56$ & 0.59 & 0.56 & - & 6.67 & 0.0032 & 0.56 \\
\hline & & Mean invertebrate biomass ${ }^{g}$ & $0.05 \pm 0.01$ & 3.35 & 0.0047 & 0.26 & & & \\
\hline & & Adjacent shorebird habitat & $2.25 \pm 0.54$ & 4.17 & 0.0009 & 0.34 & & & \\
\hline & & Nearest neighbor distance & $-0.02 \pm 0.01$ & -1.48 & 0.16 & - & & & \\
\hline
\end{tabular}

Wet area (ha) was forced as a covariate in all models. Statistics are shown for model with lowest Cp. Significant model terms (P < 0.01) are highlighted in bold, and partial $R^{2}$ values are only provided for significant model terms. Seventeen sites (df=15) in $1999-2000$ and 19 sites ( $\mathrm{df}=17)$ in 2000-2001 were included in analyses.

a Frequency of dunlin occurrence among all surveys conducted ( $n=19$ in 1999-2000, $n=18$ in 2000-2001).

b Mean bird abundance ln transformed.

c Mean bird abundance among all surveys conducted.

d Euclidean distance $(m)$ from the midpoint of sample sites to the nearest shorebird habitat edge.

e Mean number of invertebrates (all taxonomic groups combined) per $\mathrm{m}^{2}$ among collected core samples $(n=15$ in $1999-2000, n=30$ in 2000 2001).

f Amount (ha) of class 1 habitat within $2 \mathrm{~km}$ of the central coordinates of the site.

g Mean estimated invertebrate biomass $\left(\mathrm{mg} / \mathrm{m}^{2}\right.$; all taxonomic groups combined) among collected core samples $(n=15$ in $1999-2000, n=30$ in 2000-2001).

Table 3 - Results of linear regressions of killdeer use (frequency of use, mean bird abundance) on one of two food abundance measures [mean invertebrate density (individuals $/ \mathrm{m}^{2}$ ) or biomass $\left(\mathrm{mg} / \mathrm{m}^{2}\right)$ ] and landscape context [adjacent shorebird habitat (ha) and nearest neighbor distance $(\mathrm{m})]$ of wetland sites during two winters in the Willamette Valley, Oregon, USA

\begin{tabular}{|c|c|c|c|c|c|c|c|c|}
\hline Winter & Bird use response & $\begin{array}{c}\text { Parameters in model } \\
\text { with lowest } C p\end{array}$ & $\begin{array}{c}\text { Parameter } \\
\text { estimate }( \pm S E)\end{array}$ & t-value & P-value & F-value & P-value & $\begin{array}{l}\text { Model } \\
\text { adj. } R^{2}\end{array}$ \\
\hline \multirow[t]{2}{*}{ Wet 1999-2000 } & Frequency of occurrence $^{a}$ & Wet area & $2.26 \pm 1.99$ & 1.14 & 0.27 & 1.29 & 0.27 & 0.02 \\
\hline & Mean bird abundance ${ }^{b c}$ & Wet area & $0.07 \pm 0.08$ & 0.83 & 0.42 & 0.68 & 0.42 & 0.00 \\
\hline \multirow[t]{2}{*}{ Dry 2000-2001 } & Frequency of occurrence & Wet area & $-1.51 \pm 1.62$ & -0.93 & 0.37 & 0.86 & 0.37 & 0.00 \\
\hline & Mean bird abundance & Wet area & $0.96 \pm 1.96$ & 0.49 & 0.63 & 0.24 & 0.63 & 0.00 \\
\hline
\end{tabular}

Wet area (ha) was forced as a covariate in all models. Statistics are shown for model with lowest Cp. Seventeen sites $(\mathrm{df}=15)$ in $1999-2000$ and 19 sites $(\mathrm{df}=17)$ in 2000-2001 were included in analyses.

a Frequency of killdeer occurrence among all surveys conducted ( $n=19$ in 1999-2000, $n=18$ in 2000-2001).

b Mean bird abundance ln transformed.

c Mean bird abundance among all surveys conducted.

\section{Discussion}

\subsection{Influence of food abundance and landscape context}

The strong correspondence we observed between dunlin numbers and both measures of local food abundance during the dry winter (Table 2) agrees with the many studies that have documented positive relationships between shorebird abundance and prey density or biomass during the nonbreeding season (reviews by Evans and Dugan, 1984; Goss-Custard,
1984; Puttick, 1984). Dunlin are tactile foragers that probe for invertebrates in the benthos (Warnock and Gill, 1996). Although we did not collect the stomach contents of individual dunlin and therefore do not know with certainty which benthic prey items dunlin typically consume in the Valley, confirmed dunlin prey items from studies elsewhere (Skagen and Oman, 1996) dominated our measures for total abundance (small oligochaetes) and to some degree biomass (chironomid larvae) (Taft and Haig, 2005). Moreover, we anecdotally observed dunlin eating earthworms (Lumbricidae) on 
a number of occasions, another large-bodied invertebrate group influencing biomass estimates. Thus we believe our measures of food abundance adequately reflected prey items sought by dunlin, and significant positive associations between dunlin abundances and both measures of food abundance (invertebrate abundance and biomass) support this assertion.

Of perhaps greater ecological significance than the importance of food abundance was that wetland landscape context additionally influenced bird use during the dry winter. In other words, those productive sites with more adjacent shorebird habitat and closer to a wetland neighbor attracted the most birds. Not only was habitat scarce in the dry winter, but also variation among sites (min-max) in adjacent shorebird habitat (Table 1) indicated greater habitat aggregation at the spatial scale we examined ( $2 \mathrm{~km}$ radius). These various results suggest that dunlin were attracted to clusters of the limited habitat present, and with so few sites to choose from, it was important energetically to find the most productive sites within these clusters. However, large-scale distribution of habitat may also explain why we did not observe relationships between dunlin abundances and predictors during the wet winter. Not only was landscape context of wetlands unimportant, but dunlin numbers varied in no relation to differences in local food abundance. We believe that the greater availability of shorebird habitat in the wet winter may be responsible for lack of both of these relationships. In contrast to the dry winter, adjacent shorebird habitat varied among sites ( $\min -\max )$ in the wet winter by only a factor of two. Thus, relatively even spatial distribution of abundant shorebird habitat likely exerted little influence on bird distributions, and such widespread distribution of shorebird habitat may have made discriminating among sites by food abundance alone energetically unnecessary. As far as we know, no other studies of wetland bird use in relation to food resources have demonstrated the potential mediating role of landscape context. Our study indicates that the spatial distribution of habitat across the landscape may be an important force affecting the distribution of birds at a large scale and thus influencing patterns observed at a smaller wetland patch scale.

In contrast to dunlin abundances, in general frequency of occurrence at sites was unrelated to either food abundance or landscape context during both winters (Table 2). However, the 18-19 survey days accounted for only up to $14 \%$ of total possible days (roughly 135) birds may have used sites, and the time we spent at each site comprised only a fraction of the day. Moreover, we anecdotally observed sites changing dramatically in wetness (flooding then dissipating) at a finer scale (less than a week) than the frequency of our surveys. Shorebirds have been known to opportunistically find newly available habitat within days if not hours of its formation (Rundle and Fredrickson, 1981; Skagen and Knopf, 1994). Thus, our survey frequency may not have provided us with the ability to detect differences in visitation frequencies among sites.

Killdeer use frequency of occurrence and mean bird abundance) was unrelated to both local food abundance and landscape context during both the dry and wet winter. Killdeer, like most plovers, are visual foragers that peck at or immediately below the substrate surface (Baker, 1977; Jackson and Jackson, 2000). Of the invertebrates we observed among samples, commonly documented killdeer prey include earthworms (Lumbricidae) and insect larvae (chironomids and tipulids) (Skagen and Oman, 1996; Jackson and Jackson, 2000). However, in the winter these may decrease in availability at the surface when cold temperatures cause them to bury more deeply in the substrate (Esselink and Zwarts, 1989; Zwarts and Wanink, 1993) or become less active and more difficult to detect (Durell, 2000). Moreover, in terrestrial settings, killdeer also eat invertebrates such as grasshoppers (Orthoptera), beetles (Coleoptera) and sod webworms (Chrysoteuchia topiaria Zeller) (Kamm, 1973; Jackson and Jackson, 2000), invertebrates that may have been present but that we did not adequately sample. Thus, our measures for food abundance may not have been a complete reflection of the resources available to killdeer at these sites, providing one explanation for why our measures for food abundance were of little importance as predictors. Alternatively, the cosmopolitan nature of killdeer provides another explanation for lack of association with food abundance and landscape context in both winters. Although killdeer are commonly associated with wetlands, they are also found among a variety of terrestrial habitats (Jackson and Jackson, 2000). Thus because potential killdeer foraging habitat includes more habitat types than shorebird habitat, usable habitat may have been perceived by killdeer as so widespread that its distribution was inconsequential, and finding the most productive sites was of little importance in surviving the winter. Other researchers have similarly found a lack of association between use of sites by generalist species and landscape context when measured as the availability of specific habitat types in surrounding landscapes (Naugle et al., 1999; Calmé and Desrochers, 2000; Best et al., 2001).

Our results for dunlin complement a new but growing recognition of the importance of landscape context to wetland birds during all phases of their annual cycle. During nonbreeding periods, importance of landscape context to foraging waterbirds has been demonstrated by only a few other studies in addition to ours: for coastal agricultural wet grasslands (Milsom et al., 1998), coastal wetlands (Lovvorn and Baldwin, 1996), and inland ricefields (Elphick, 1998). If food abundance is a significant determinant of wetland bird use in these systems, landscape context is likely a mediating influence in these landscapes as well. Our findings suggest that at least in the Valley, there is some limit to the amount of available habitat in the landscape below which landscape context becomes influential and discriminating among sites according to food abundance confers energetic advantages. Above this limit, discerning among sites of variable food abundance becomes less important because habitat is so widely available across the landscape. As we further our understanding of ecological processes in wetland landscapes, it will be of increasing interest to know if similar relationships occur elsewhere. Although a traditional research focus on within-wetland processes will continue to be important, clearly we have more to learn by studying wetlands in the context of the landscapes in which they are found. 


\subsection{Implications for wetland landscape planning}

With past and present losses to wetland habitat in the Valley and elsewhere (Dahl, 1990; Bernert et al., 1999; Taft and Haig, 2003), many agencies and coalitions recognize the need to conserve (i.e., protect, enhance, and restore) wetland habitat (e.g., National Research Council, 1992; Good and Sawyer, 1998; Morlan, 2000; Brown et al., 2001). While conservation efforts to increase invertebrate abundance within existing or restored wetlands will always be of value to waterbirds, our study indicates that consideration of where to spatially focus these efforts may be of primary importance for wetland landscapes that vary annually in the distribution of habitat.

Especially during a dry year, our results imply that an enhanced or restored site that is isolated will be used less and thus not as beneficial to birds as one that is located near other favorable habitat. Thus, to benefit birds over the entire range of potential winter conditions, planners should conserve clusters of dependable habitat that are wet in most years (also see Riffell et al., 2003). Potential sites located near reliable wetland habitat in dry years (e.g., refuge impoundments, habitually flooded agricultural lands) should receive conservation priority. Enhancing invertebrate productivity within these prioritized sites would then be the next step in conservation planning. A thorough review of techniques developed to augment invertebrates is beyond the scope of this paper. However, the presence of decomposing organic matter and regular fluctuations in flooding regime are two principal features of freshwater wetlands contributing to invertebrate productivity (Fredrickson and Laubhan, 1994; Rehfisch, 1994; Anderson and Smith, 2000). Agricultural management practices or restoration techniques that promote these will be of foremost importance.

For most wetland landscapes, limited resources for conservation (funding, personnel) call for the most efficient landscape planning possible. For many wetland landscapes, we believe strategic consideration of wetland location may be key to such efficient planning. Bringing greater long-term benefits to wildlife, such an approach to wetland restoration and management should be preferable to one that is opportunistic and non-spatial. Potential for such planning will only increase with further study of wildlife-habitat associations in entire wetland landscapes.

\section{Acknowledgments}

We are indebted to J. Dhundale, M. Henschen, W. Jensen, H. Packard, and M. Taft for their immense effort in collecting and managing field data, and to W. Jensen, R. Moran, and H. Packard for sorting hundreds of samples in the lab. We also thank J. Beall, K. Bierly, M. Colwell, R. Goggans, J. Houk, J. Morlan, M. Naughton, P. Sanzenbacher, C. Schuler, S. Smith, B. Taylor, and T. Zimmerman for advice, technical and logistical assistance, and G. Lienkaemper, C. Kiilsgaard, D. Oetter, and R. Kennedy for GIS support. This work benefited from discussions with G. Bradshaw, W. Gerth, J. Hayes, R. Hoffman, W. Hohman, M. Huso, D. Kesler, D. Lank, L. Oring, P. Sanzenbacher, N. Schumaker, J. Steiner, and L. Weber. Project funding was generously provided by the USGS Forest and Rangeland Ecosystem Science Center, US Fish and Wild- life Service, Oregon Department of Fish and Wildlife, Oregon Watershed Enhancement Board, and Bureau of Land Management.

\section{R E F E R E N C E S}

Anderson, J.T., Smith, L.M., 2000. Invertebrate responses to moist-soil management of playa wetlands. Ecological Applications 10, 550-558.

Ashley, M.C., Robinson, J.A., Oring, L.W., Vinyard, G.A., 2000. Dipteran standing stock biomass and effects of aquatic bird predation at a constructed wetland. Wetlands 20, 84-90.

Baker, M.C., 1977. Shorebird food habits in the eastern Canadian Arctic. Condor 79, 56-62.

Benner, P.A., Sedell, J.R., 1997. Upper Willamette River landscape: a historic perspective. In: Laenen, A., Dunnette, D.A. (Eds.), River Quality: Dynamics and Restoration. Lewis Publishers, New York, pp. 23-47.

Bernert, J.A., Eilers, J.M., Eilers, B.J., Blok, E., Daggett, S.G., Bierly, K.F., 1999. Recent wetlands trends (1981/82-1994) in the Willamette Valley, Oregon, USA. Wetlands 19, 545-559.

Best, L.B., Bergin, T.M., Freemark, K.E., 2001. Influence of landscape composition on bird use of rowcrop fields. Journal of Wildlife Management 65, 442-449.

Brown, S., Hickey, C., Harrington, B., Gill, R., 2001. The U.S. Shorebird Conservation Plan, 2nd ed. Manomet Center for Conservation Sciences, Manomet, MA.

Calmé, S., Desrochers, A., 2000. Biogeographic aspects of the distribution of bird species breeding in Quebec's peatlands. Journal of Biogeography 27, 725-732.

Castro, G., Myers, J.P., 1989. Flight range estimates for shorebirds. The Auk 106, 474-476.

Clark, S.E., White, D., Schaedel, A.L., 1991. Oregon, USA, ecological regions and subregions for water quality management. Environmental Management 15, 847-856.

Cohen, J., 1988. Statistical Power Analysis for the Behavioral Sciences, 2nd ed. Lawrence Erlbaum Associates, Hillsdale, NJ.

Colwell, M.A., Landrum, S.L., 1993. Nonrandom shorebird distribution and fine-scale variation in prey abundance. Condor 95, 94-103.

Colwell, M.A., Oring, L.W., 1988. Habitat use by breeding and migrating shorebirds in southcentral Saskatchewan. Wilson Bulletin 100, 554-566.

Cowardin, L.M., Carter, V., Golet, F.C., LaRoe, E.T., 1979. Classification of wetlands and deepwater habitats of the United States. U.S. Fish and Wildlife Service, Washington, DC

Daggett, S.G., Boulé, M.E., Bernert, J.A., Eilers, J.M., Blok, E., Peters, D., Morlan, J., 1998. Wetland and land use changes in the Willamette Valley, Oregon: 1982 to 1994. Report to the Oregon Division of State Lands, Shapiro and Associates, Inc., Portland, OR.

Dahl, T.E., 1990. Wetlands: Losses in the United States 1780 s to 1980s. U.S. Fish and Wildlife Service, Washington, DC.

Dunning, J.B., Danielson, B.J., Pulliam, H.R., 1992. Ecological processes that affect populations in complex landscapes. Oikos 65, 169-175.

Durell, S.E.A.le V. dit., 2000. Individual feeding specialization in shorebirds: population consequences and conservation implications. Biological Reviews 75, 503-518.

Elphick, C.S., 1998. Waterbird conservation and ecology: the role of rice field management in habitat restoration. Ph.D. Thesis, University of Nevada, Reno, NV.

Esselink, P., Zwarts, L., 1989. Seasonal trend in burrow depth and tidal variation in feeding activity of Nereis diversicolor. Marine Ecology Progress Series 56, 243-254. 
Evans, P.R., 1976. Energy balance and optimal foraging strategies in shorebirds: some implications for their distributions and movements in the non-breeding season. Ardea 64, 117-139.

Evans, P.R., Dugan, P.J., 1984. Coastal birds: numbers in relation to food resources. In: Evans, P.R., Goss-Custard, J.D., Hale, W.G. (Eds.), Coastal Waders and Wildfowl in Winter. Cambridge University Press, Cambridge, UK, pp. 8-28.

Fairbairn, S.E., Dinsmore, J.J., 2001. Local and landscape-level influences on wetland bird communities of the Prairie Pothole Region of Iowa, USA. Wetlands 21, 41-47.

Farmer, A.H., Parent, A.H., 1997. Effects of the landscape on shorebird movements at spring migration stopovers. Condor 99, 698-707.

Farmer, A.H., Wiens, J.A., 1999. Models and reality: time-energy trade-offs in Pectoral Sandpiper (Calidris melanotos) migration. Ecology 80, 2566-2580.

Fredrickson, L.H., Laubhan, M.K., 1994. Managing wetlands for wildlife. In: Bookhout, T.A. (Ed.), Research and Management Techniques for Wildlife and Habitats. The Wildlife Society, Bethesda, MD, pp. 623-647.

Fredrickson, L.H., Reid, F.A., 1986. Wetland and riparian habitats: a nongame management overview. In: Hale, J.B., Best, L.B., Clawson, R.L. (Eds.), Management of Nongame Wildlife in the Midwest: A Developing Art. The Wildlife Society, Grand Rapids, MI, pp. 59-96.

Good, J.W., Sawyer, C.B., 1998. Recommendations for a Nonregulatory Wetland Restoration Program for Oregon. Oregon Sea Grant, Corvallis, OR.

Goss-Custard, J.D., 1984. Intake rates and food supply in migrating and wintering shorebirds. In: Burger, J., Olla, B.L. (Eds.), Shorebirds: Migration and Foraging Behavior. Plenum, New York, pp. 233-271.

Haig, S.M., Mehlman, D.W., Oring, L.W., 1998. Avian movements and wetland connectivity in landscape conservation. Conservation Biology 12, 749-758.

Helmers, D.L.,1991. Habitat use by migrant shorebirds and invertebrate availability in a managed wetland complex. MS Thesis, University of Missouri, Columbia, MO.

Hulse, D., Gregory, S., Baker, J., 2002. Willamette River Basin Planning Atlas: Trajectories of Environmental and Ecological Change. Edited for the Pacific Northwest Ecosystem Research Consortium, Oregon State University Press, Corvallis, OR.

Jackson, B.J.S., Jackson, J.A., 2000. Killdeer (Charadrius vociferus). In: Poole, A., Gill, F. (Eds.), The Birds of North America. No. 517. The Birds of North America, Inc., Philadelphia, PA.

Jackson, P.L., Kimerling, A.J., 1993. Atlas of the Pacific Northwest. Oregon State University Press, Corvallis, OR.

Kadlec, J.A., 1962. Effects of a drawdown on a waterfowl impoundment. Ecology 43, 267-281.

Kalejta, B., Hockey, P.A.R., 1994. Distribution of shorebirds at the Berg River estuary, South Africa, in relation to foraging mode, food supply and environmental features. Ibis 136, 233-239.

Kamm, J.A., 1973. Biotic factors that affect sod webworms in grass seed fields in Oregon. Environmental Entomology 2, 94-96.

Kersten, M., Piersma, T., 1987. High levels of energy expenditure in shorebirds: metabolic adaptations to an energetically expensive way of life. Ardea 75, 175-187.

Krapu, G.L., Reinecke, K.J., 1992. Foraging ecology and nutrition. In: Batt, B.D.J., Afton, A.D., Anderson, M.G., Ankeny, C.D., Johnson, D.H., Kadlec, J.A., Krapu, G.L. (Eds.), Ecology and Management of Breeding Waterfowl. University of Minnesota Press, Minneapolis, MN, pp. 1-29.

Lovvorn, J.R., Baldwin, J.R., 1996. Intertidal and farmland habitats of ducks in the Puget Sound Region: a landscape perspective. Biological Conservation 77, 97-114.

Mercier, F., McNeil, R., 1994. Seasonal variation in intertidal density of invertebrate prey in a tropical lagoon and effects of shorebird predation. Canadian Journal of Zoology 72, 1755-1763.

Merrit, R.W., Cummins, K.W., 1984. An Introduction to the Aquatic Insects of North America, 2nd ed. Kendall/Hunt Publishing Company, Dubuque, IA.

Milsom, T.P., Ennis, D.C., Haskell, D.J., Langton, S.D., McKay, H.V., 1998. Design of grassland feeding areas for waders during winter: the relative importance of sward, landscape factors and human disturbance. Biological Conservation 84, 119-129.

Morlan, J.C., 2000. Summary of current status and health of Oregon's freshwater wetlands. In: Oregon State of Environment Report 2000. Division of State Lands, Salem, OR, pp. 45-52.

Murkin, H.R., Kadlec, J.A., 1986. Relationships between waterfowl and macroinvertebrate densities in a northern prairie marsh. Journal of Wildlife Management 50, 212-217.

Murkin, H.R., Murkin, E.J., Ball, J.P., 1997. Avian habitat selection and prairie wetland dynamics: a 10-year experiment. Ecological Applications 7, 1144-1159.

Myers, J.P., 1983. Conservation of migrating shorebirds: staging areas, geographic bottlenecks, and regional movements. American Birds 37, 23-25.

National Research Council, 1992. Restoration of Aquatic Ecosystems: Science, Technology, and Public Policy. National Academy Press, Washington, DC.

Naugle, D.E., Higgins, K.F., Nusser, S.M., Johnson, W.C., 1999. Scale-dependent habitat use in three species of prairie wetland birds. Landscape Ecology 14, 267-276.

Office of Information Resources Management, 1994. Pacific Northwest (PNW) 1:100,000 river reach file system, version 2.1. Pacific States Marine Fisheries Service, US Geological Survey, Environmental Protection Agency, Washington, DC.

Pennak, R.W., 1989. Freshwater Invertebrates of the United States: Protozoa to Mollusca, 3rd ed. Wiley, New York.

Puttick, G.M., 1984. Foraging and activity patterns in wintering shorebirds. In: Burger, J., Olla, B.L. (Eds.), Shorebirds: Migration and Foraging Behavior. Plenum, New York, pp. 203-233.

Pyke, G.H., 1983. Animal movements: an optimal foraging approach. In: Swingland, I.R., Greenwood, P.J. (Eds.), The Ecology of Animal Movement. Clarendon Press, Oxford, pp. 7-31.

Ramsey, F.L., Schafer, D.W., 1997. The Statistical Sleuth: A Course in Methods of Data Analysis. Wadsworth Publishing Company, Belmont, CA.

Rehfisch, M.M., 1994. Man-made lagoons and how their attractiveness to waders might be increased by manipulating the biomass of an insect benthos. Journal of Applied Ecology 31, 383-401.

Riffell, S.K., Keas, B.E., Burton, T.M., 2003. Birds in North American Great Lakes coastal wet meadows: is landscape context important? Landscape Ecology 18, 95-111.

Roshier, D.A., Robertson, A.I., Kingsford, R.T., 2002. Responses of waterbirds to flooding in an arid region of Australia and implications for conservation. Biological Conservation 106, 399-411.

Rottenborn, S.C., 1996. The use of coastal agricultural fields in Virginia as foraging habitat by shorebirds. Wilson Bulletin 108, 783-796.

Rundle, W.D., Fredrickson, L.H., 1981. Managing seasonally flooded impoundments for migrant rails and shorebirds. Wildlife Society Bulletin 9, 80-87.

Safran, R.J., Isola, C.R., Colwell, M.A., Williams, O.E., 1997. Benthic invertebrates at foraging locations of nine waterbird species in managed wetlands of the northern San Joaquin Valley, California. Wetlands 17, 407-415.

Sanzenbacher, P.M., Haig, S.M., 2002a. Residency and movement patterns of wintering Dunlin in the Willamette Valley of Oregon. Condor 104, 271-280.

Sanzenbacher, P.M., Haig, S.M., 2002b. Regional fidelity and movement patterns of wintering Killdeer in an agricultural landscape. Waterbirds 25, 16-25. 
SAS Institute Inc., 1999. The SAS system for windows, version 8.2. Cary, NC, USA.

Sherfy, M.H., Kirkpatrick, R.L., Richkus, K.D., 2000. Benthos core sampling and chironomid vertical distribution: implications for assessing shorebird food availability. Wildlife Society Bulletin 28, 124-130.

Shriver, W.G., Hodgman, T.P., Gibbs, J.P., Vickery, P.D., 2004. Landscape context influences salt marsh bird diversity and area requirements in New England. Biological Conservation 119, 545-553.

Skagen, S.K., Knopf, F.L., 1994. Migrating shorebirds and habitat dynamics at a prairie wetland complex. Wilson Bulletin 106, 91-105.

Skagen, S.K., Oman, H.D., 1996. Dietary flexibility of shorebirds in the western hemisphere. Canadian Field-Naturalist 110, 419-444.

Taft, O.W., Haig, S.M., 2003. Historical wetlands in Oregon's Willamette Valley: implications for restoration of winter waterbird habitat. Wetlands 23, 51-64.

Taft, O.W., Haig, S.M., Kiilsgaard, C., 2004. Use of radar remote sensing (RADARSAT) to map winter wetland habitat for shorebirds in an agricultural landscape. Environmental Management 33, 749-762.

Taft, O.W., Haig, S.M., in press. Importance of wetland landscape structure to shorebirds wintering in an agricultural valley. Landscape Ecology.
Taft, O.W., Haig, S.M., 2005. The value of agricultural wetlands as invertebrate resources for wintering shorebirds. Agriculture, Ecosystems \& Environment 110, 249-256.

Warnock, N.D., Gill, R.E., 1996. Dunlin (Calidris alpina). In: Poole, A., Gill, F. (Eds.), The Birds of North America. No. 203. The Birds of North America., Inc., Philadelphia, PA.

Weber, L.M., Haig, S.M., 1996. Shorebird use of South Carolina managed and natural coastal wetlands. Journal of Wildlife Management 60, 73-82.

Weber, L.M., Haig, S.M., 1997. Shorebird-prey interactions in South Carolina coastal soft sediments. Canadian Journal of Zoology 75, 245-252.

Weller, M.W., 1978. Management of freshwater marshes for wildlife. In: Good, R.E., Whigham, D.F., Simpson, R.L. (Eds.), Freshwater Wetlands: Ecological Processes and Management Potential. Academic Press, New York, pp. 267-284.

Weller, M.W., 1987. Freshwater Marshes: Ecology and Wildlife Management. University of Minnesota Press, Minneapolis, MN.

Wu, J., Hobbs, R., 2002. Key issues and research priorities in landscape ecology: an idiosyncratic synthesis. Landscape Ecology 17, 355-365.

Zwarts, L., Wanink, J., 1993. How the food supply harvestable by waders in the Wadden Sea depends on the energy content, body weight, biomass, burying depth and behaviour of tidal-flat invertebrates. Netherlands Journal of Sea Research 31, 441-476. 